\title{
Can Atorvastatin Modulate The Impact Of Oxidative Stress On Testicular Tissue In Diabetic Rats?
}

\author{
Eman A. Shaat*, Gehan Y. Soliman** \\ Medical Biochemistry* and Physiology** Departments \\ Faculty of Medicine, Alexandria University,Egypt.
}

\begin{abstract}
The aim of the present study was to evaluate the effect of atorvastatin on some oxidative markers in testes of streptozotocin(STZ)-induced diabetic rats. This study included thirty adult male albino rats divided equally into control group (I), nontreated diabetic group (II) and atorvastatin-treated diabetic group (III). After eight weeks, all rats were sacrificed. In testes, xanthine oxidase $(X O)$ and NADPH oxidase enzyme activities were determined. In addition, reactive oxygen species(ROS) levels were measured using dichlorofluorescein method. Testicular hemeoxygenase-1(HO1), testosterone and coenzyme Q10 (CoQ10) were estimated by ELISA and HPLC techniques respectively.

The results of this study showed that in STZ-induced diabetic rats, XO and NADPH oxidase activities as well as ROS and HO-1 levels increased significantly as compared to control values, while CoQ10 decreased significantly. Administration of atorvastatin to diabetic rats could significantly reduce XO and NADPH oxidase activities and ROS levels. In addition, it increased CoQ10 and testosterone testicular levels but without apparent effect on hyperglycemia or HO-1 levels. XO, NADPH oxidase, ROS, HO-1 and glucoce was found to correlate positively to each other. In contrast, CoQ10 was inversely correlated to the previously mentioned parameters.

These data support the protective antioxidant effect of atorvastatin. This drug could attenuate the oxidative stress induced in testes of STZ-diabetic rats possibly through decreasing XO and NADPH oxidase activities as well as ROS levels and also through increasing antioxidant CoQ10 levels. However, it could not modulate hyperglycemia or testicular HO-1 levels.
\end{abstract}

\section{INTRODUCTION}

Diabetes mellitus (DM) is one of the most common metabolic diseases which is commonly associated with impairment of testicular functions, ultimately leading to reduced fertility in men and animal models ${ }^{(1,2)}$. The exact pathophysiology mechanism of altered male reproductive function in diabetics remains obscure. However, enhanced oxidative stress and changes in antioxidant capacity could be considered to play a role in the pathogenesis of chronic diabetic complications $^{(2,3)}$.

Multiple

biochemical mechanisms have been proposed to increase oxidative stress in diabetes. Among these mechanisms, xanthine oxidase (XO) and the reduced form of nicotinamide adenine dinucleotide phosphate oxidase (NADPH oxidase) 
enzymes have been known to produce reactive oxygen species (ROS) and contribute to oxidative stress ${ }^{(4,5)}$.

Xanthine oxidase (XO; EC 1.17.3.2) is implicated in the control of various redox reactions in the cells especially for purine metabolism with hydrogen peroxide $\left(\mathrm{H}_{2} \mathrm{O}_{2}\right)$ production. Under some conditions, the product may be superoxide anion $\left(\mathrm{O}^{-\bullet}\right)$ rather than $\mathrm{H}_{2} \mathrm{O}_{2}$. Xanthine oxidoreductase group has 2 distinct forms; a constitutively expressed form xanthine dehydrogenase, and a posttranscriptional modified form originated by spontaneous proteolytic cleavage consisting of four discrete fragments, the main one is xanthine oxidase $^{(6)}$. The conversion of dehydrogenase to oxidase occurs in tissue injury ${ }^{(7)}$.

NADPH oxidases (NOX; EC 1.6.3.1) are professional superoxideproducing enzymes. The best studied among them is phagocyte NADPH oxidase which consists of a dimmer of a transmembrane subunit gp91 $1^{\text {phox }}$, $\mathrm{p} 22^{\text {phox }}$, and four cytosolic subunits of p6 $7^{\text {phox }}, \mathrm{p} 47^{\text {phox }}, \mathrm{p} 40^{\text {phox }}$ and rac- $2^{(8)}$. When NADPH oxidase is activated, it transports electrons from intracellular NADPH to extracellular oxygen resulting in $\mathrm{O}^{-\bullet}$ generation which then reacts with proton to form $\mathrm{H}_{2} \mathrm{O}_{2}$. The NOX family consists of 7 members. In testis, NOX 5 iso-enzyme is highly expressed which contains an Nterminal extension with three EF hand motifs and is able to produce $\mathrm{O}^{-\bullet}$ and to conduct hydrogen ion in response to cytosolic free calcium elevations. So, it might have a function in spermatogenesis and sperm biology ${ }^{(9)}$.

ROS generated endogenously or in response to stress have long been implicated in tissue injury and may cause cell death. Cells have evolved numerous survival pathways which include activation of stress-related protein response. Among these, is the hemeoxygenase-1 system (HO-1). Hemeoxygenase (HO; EC 1.14.99.3) is the rate-limiting step in the heme degradation to form biliverdin and carbon monoxide $(\mathrm{CO})$. To date, three identified $\mathrm{HO}$ isoforms are part of $\mathrm{HO}$ system. These are inducible HO-1 or heat shock protein-32 (HSP-32), constitutive HO-2 and -3 . HO-1 and 2 were detected in rat testis. HO-1 have a modulatory role in spermatogenesis under conditions of stress $^{(10)}$

Co enzyme Q (CoQ) is a highly lipophilic compound which is widely distributed in cell membranes especially inner mitochondrial membrane. CoQ has a dual function as it is essential for production of cellular energy and can act as antioxidant by different mechanisms ${ }^{(11,12)}$. Mitochondria can contribute to the development of chronic diabetes mellitus because they generate a great amount of ROS. This could stimulate its complications especially in testis since reproductive function is heavily dependent on the energy generated by mitochondria ${ }^{(\mathbf{1 1})}$.

Atorvastatin is a second generation synthetic 3-Hydroxy-3methyl-glutaryl CoA (HMG-CoA) reductase inhibitor used to treat hypercholesterolemia especially in diabetics with controversial effects on glycemic control and gonadal steroidogenesis $\left.^{(13,14}\right)$. The list of different pleiotropic effects of statins is still growing which includes either 
cholesterol-dependent or-independent effects $^{(15,16)}$.

\section{AIM OF THE WORK}

The aim of the present study was to evaluate the role of some ROSgenerating enzymes (xanthine oxidase and NADPH oxidase) and some endogenous antioxidants (HO- 1 and CoQ10) in testes of streptozotocininduced chronic diabetic rats. In addition, it aimed to clarify whether atorvastatin can protect the testes of diabetic rats against oxidative stress.

\section{METHODS}

Chemicals: All chemicals were purchased from Sigma-Aldrich Co. (St Louis, USA). Solvents were of HPLC grade.

Animals: The present study was conducted on 40 adult male albino rats (150-200 gm body weight). The rats were housed under the same environmental conditions, five animals per cage, and given free access to normal laboratory diet and water. All procedures conformed to the guidelines for the care and handling of animals. Only 30 rats remained alive and were classified into three groups:

Group I (Control group): included 10 normal rats received single intraperitonial (i.p.) injection of citrate buffer (vehicle buffer).

Group II (Diabetic group): included 10 diabetic rats. DM was induced by single i.p. injection of $50 \mathrm{mg} / \mathrm{kg}$ body weight streptozotocin (STZ) in $10 \mathrm{mM}$ citrate buffer $\mathrm{pH}$ 4.5. Animals were considered diabetic when the fasting blood glucose levels were $>250$ $\mathrm{mg} / \mathrm{dl}$.

Group III (Atorvastatin-treared group): included 10 diabetic rats, each one of them received $1 \mathrm{ml}$ atorvastatin (Lipitor-Pfizer) suspended in 2\% gum acacia orally in a dose of $10 \mathrm{mg} / \mathrm{kg}$ body weight/day for 8 weeks starting 24 hours after induction of DM.

Insulin was administered once a day subcutaneously for 8 weeks in a dose of $4 \mathrm{U} / \mathrm{kg}$ in the two diabetic groups.

At the end of the experiment (after 8 weeks), all rats were fasted overnight. They were etheranaesthetized and blood was collected from retro-orbital venous plexus and serum was separated. Serum glucose and cholesterol was estimated by enzymatic methods (Stanbio Laboratory Inc.,). Then rats were scarificed by decapitation, and the 2 testes from each rat were quickly removed, washed with ice-cold saline, and stored at $-80^{\circ} \mathrm{C}$ in 5 portions until analysis.

\section{Biochemical analysis}

Xanthine oxidase (XO) activity: A testicular portion from each rat was homogenized in $150 \mathrm{mM}$ sucrose and $100 \mathrm{mM}$ Tris- $\mathrm{HCl}$ buffer $\mathrm{pH} 8$; before use dithiothreitol (final concentration $10 \mathrm{mM}$ ) was added to this solution. The homogenate was centrifuged for 30 min. at $15000 \times \mathrm{xg}$ and the supernatant was used for determination of protein concentration and XO activity. Protein concentration was estimated by Lowry method (17) in different preparations using bovine serum albumin as a standard. The incubation mixture for $\mathrm{XO}$ contained $50 \mathrm{mM}-$ tris/ $\mathrm{HCl}$ buffer, $\mathrm{pH}$ 8.0, $50 \mu \mathrm{M}$ xanthine and enzyme 
preparation containing $300-500 \mu \mathrm{g}$ protein. XO enzymatic activity was measured as formation of uric acid at $302 \mathrm{~nm}$ using molar absorption coefficient of $7.12 \mathrm{mM}^{-1} \mathrm{~cm}^{-1(18)}$. XO activity was finally expressed as $\mathrm{nM} / \mathrm{min}$./mg protein.

NADPH oxidase activity: Frozen testicular tissue was homogenized in $50 \mathrm{mM}$ tris- $\mathrm{HCl}$ buffer (pH 7.4) containing $0.1 \mathrm{mM}$ EDTA, $0.1 \mathrm{mM}$ EGTA and antiproteolytic agents $(1 \mathrm{mM}$ phenylmethylsulfonylfluoride

(PMSF), $1 \mu \mathrm{M}$ pepstatin and $2 \mu \mathrm{M}$ leupeptin). Samples were centrifuged at $750 \mathrm{xg}$ for $10 \mathrm{~min}$. and supernatants were saved for assay of NADPHdependent superoxide production. $\mathrm{O}^{-\bullet}$ generating activity was assayed using superoxide dismutase(SOD)inhibitable cytochrome c reduction, measured at $550 \mathrm{~nm}$, and extinction coefficient of $21.1 \mathrm{mM}^{-1} \mathrm{~cm}^{-1}(\mathbf{1 9 , 2 0})$. The sample cuvette contained $80 \mu \mathrm{M}$ cytochrome $\mathrm{c}$ and sample in buffer (23mM phosphate buffer, $\mathrm{pH} 7.0$ containing $100 \mathrm{mM} \mathrm{KCl}, 8 \mathrm{mM} \mathrm{MgCl} 2$ and $3.3 \mathrm{mM} \mathrm{NaCl}$ ). The reference cuvette contained the same components plus SOD $(80 \mu \mathrm{g} / \mathrm{ml})$. The reaction was initiated after $3 \mathrm{~min}$. preincubation at $37^{\circ} \mathrm{C}$ by the addition of $0.14 \mathrm{mM}$ NADPH (final) to both the sample and reference cuvettes. Results were expressed as $\mathrm{nM} \mathrm{\textrm {O } ^ { - \bullet }}$ produced/min./mg protein.

Testicular ROS content: It was measured using 2', 7'dichlorofluorescein diacetate (DCFHDA). DCFH-DA can be hydrolyzed to non-fluorescent 2', 7'dichlorofluorescein (DCFH). DCFH is rapidly oxidized to highly fluorescent DCF in the presence of $\mathrm{H}_{2} \mathrm{O}_{2}{ }^{(21,22)}$. A portion of testis from each rat was homogenized in $50 \mathrm{mM}$ tris- $\mathrm{HCl}$; $\mathrm{pH}$ 7.4. The homogenate was diluted with phosphate- buffered saline $(\mathrm{pH}$ 7.4) and then loaded with $5 \mu \mathrm{M}$ DCFH-DA (added as a stock of $10 \mathrm{mM}$ in dimethylsulfoxide). After incubation for $45 \mathrm{~min}$. at $37^{\circ} \mathrm{C}$, the fluorescence measured for up to 60 min. after the addition of DCFH-DA using fluorescence spectrophotometer with an excitation wavelength of 485 $\mathrm{nm}$ and an emission wavelength of $530 \mathrm{~nm}$. A standard curve was constructed using 2', $7^{\prime}$ dichlorofluorescein (DCF) and the results were expressed as $\mu \mathrm{M}$ $\mathrm{DCF} / \mathrm{mg}$ protein.

Hemeoxygenase-1(HO-1): Its concentration was quantitated in testis using Stressgen's StressXpress rat HO-1 ELISA kit $^{\text {(23) }}$ (Stressgen Bioreagents Corporation, Canada). Another part of testis from each rat was homogenized in tissue extraction buffer (provided in the Kit) supplemented with protease inhibitors (0.1 mM PMSF, $1 \mu \mathrm{g} / \mathrm{ml}$ leupeptin, $1 \mu \mathrm{g} / \mathrm{ml}$ aprotinin, $1 \mu \mathrm{g} / \mathrm{ml}$ pepstatin). The homogenate was centrifuged at $21000 \mathrm{xg}$ for $10 \mathrm{~min}$. and the supernatant was collected, and stored in aliquots at $-80^{\circ} \mathrm{C}$ until assayed for $\mathrm{HO}-1$ and protein. This kit is specific for rat HO-1. Its sensitivity was 0.78 $\mathrm{ng} / \mathrm{ml}$. Intra- and inter- assay coefficient of variation ( $\mathrm{CV} \%$ ) has been determined by kit manufacturers' to be less than $10 \%$. Testicular HO-1 concentrations were expressed as $\mathrm{ng} / \mathrm{mg}$ protein.

Coenzyme Q10 (CoQ10) estimation: Tissue extraction: Direct extraction with ethanol n-hexane was used $^{(24)}$. Approximately $200 \mathrm{mg}$ of 
frozen tissue was homogenized with $2 \mathrm{ml}$ water. One $\mathrm{ml}$ was used for CoQ10 estimation and the other $\mathrm{ml}$ was stored at $-80^{\circ} \mathrm{C}$ until assayed for testosterone. $50 \mu \mathrm{l}$ of BHT (2, 6-Ditetra-butyl-p-cresol) in ethanol (10 $\mathrm{mg} / \mathrm{ml}$ ) was added to $1 \mathrm{ml}$ homogenate of each sample to prevent auto-oxidation. Each sample was mixed with $2 \mathrm{ml}$ ethanol to remove protein and denature enzymes. Then 2 $\mathrm{ml}$ hexane was added, and the tightly capped tube was vigorously vortexmixed for $2 \mathrm{~min}$. After centrifugation at $2200 \mathrm{rpm}$ for $5 \mathrm{~min}$., the hexane organic supernatant was transferred to a small vial. Hexane extraction was repeated, and the combined extracts were evaporated to dryness. The residue was re-dissolved in isopropanol.

CoQ10 quantification: HPLC separation of the sample solution was performed shortly after its reconstitution on a spherisorb $\mathrm{RP}_{18} 5$ micro 220x4.6 $\mathrm{mm}$ (Brownlee column) with a mobile phase composed of isopropanol-methanoltetrahydrofuran in the ratio of $55: 39$ : $6(\mathrm{v} / \mathrm{v} / \mathrm{v})^{(25)}$ at a flow rate of $1.0 \mathrm{ml} / \mathrm{min}$. Under these chromatographic conditions, the CoQ10 had retention time of approximately $4.38 \mathrm{~min}$. The peaks were detected at UV $275 \mathrm{~nm}$. The concentrations of samples were calculated from a standard curve as area under the curve using different dilutions of CoQ10 standard in ethanol (1.25-40 $\mu \mathrm{g} / \mathrm{ml})$. Protein was determined in the homogenized sample before ethanol addition and CoQ10 concentration in testis was finally expressed as $\mathrm{ng} / \mathrm{mg}$ protein.
Testosterone concentration: It was estimated in the thawed testicular homogenate after ether extraction ${ }^{(\mathbf{2 6})}$ The dried supernatants were reconstituted in the buffer of ELISA kit (Fertigenix, Biosource, Europe). The minimum detection level was reported by the kit manufacturers' to be $<0.07 \mathrm{ng} / \mathrm{ml}$. The intra- and interassay $\mathrm{CV} \%$ ranged from 6.2 to $8.5 \%$ and from 6.4 to $7.3 \%$ respectively. The cross reactivity with other steroids was $<1 \%$. The final concentration was expressed as ng/mg protein.

\section{Statistical analysis:}

SPSS version 10.0 software(SPSS Inc.,Chicago,IL) was used for statistical analysis and $\mathrm{p}$ less than 0.05 was cosidered significant for all analysis. Results were expressed as mean and standard deviation(S.D.). ANOVA test was performed to compare between the groups. Association between different parameters were determined using Pearson's correlation coefficient.

\section{RESULTS}

In table I, testicular levels of oxidants as presented by $\mathrm{XO}$ and NADPH oxidase activities as well as ROS levels showed significant higher levels in the non-treated diabetic rats (p $<$ 0.0001). Atorvastatin administration to diabetic rats could decrease their levels when compared to non-treated diabetics ( $\mathrm{p}<0.0001$, $\mathrm{p}<0.001$ and $\mathrm{p}<0.0001$ respectively). However, maximal protective effect of atorvastatin was evident with $\mathrm{XO}$ activity.

Results of testicular antioxidants were shown in table II. HO-1was 
increased significantly either in nontreated or atorvastatin-treated diabetic rats $(\mathrm{p}<0.0001)$. CoQ10 levels decreased significantly in the nontreated diabetic group ( $p<0.0001)$. Atorvastatin administration could improve CoQ10 levels to be nearly similar to normal control.

Testosterone in the testes of nontreated diabetic rats did not differ significantly from that of control ones ( $>$ 0.05). However, atorvastatin elevated testosterone levels as compared to both control and nontreated diabetic groups $(\mathrm{p}<$ 0.05)(Table II).

Table III shows that serum glucose and cholesterol levels increase significantly in the STZ-induced diabetic groups $(\mathrm{p}<0.0001, \mathrm{p}<0.001$ respectively). Atorvastatin administration decreased cholesterol level significantly $(p<0.05)$ in the diabetic rats but failed to decrease their glucose concentration.

Correlation studies revealed that values for $\mathrm{XO}$, NADPH oxidase, ROS, HO-1 and glucose showed direct correlation with each other $(\mathrm{p}<$ 0.01 except for $\mathrm{XO}$ with glucose where $\mathrm{p}<0.05)$. In contrast, CoQ10 was only inversely correlated to the previously mentioned parameters $(\mathrm{p}<$ 0.01 ). Testosterone was only directly correlated to HO-1 $(\mathrm{p}<0.01)$ (Table IV).

TABLE (I): Xanthine oxidase \& NADPH oxidase activities (nM/min./mg protein) and total reactive oxygen species (ROS) levels $(\mu \mathrm{M} / \mathrm{mg}$ protein) in the testes of the studied rats.

\begin{tabular}{|c|c|c|c|c|}
\hline & $\begin{array}{c}\text { Group I } \\
\text { (control) } \\
n=10\end{array}$ & $\begin{array}{c}\text { Group II } \\
\text { (non-treated } \\
\text { diabetic) } \\
n=10\end{array}$ & $\begin{array}{l}\text { Group III } \\
\text { (atorvastatin- } \\
\text { treated diabetic) } \\
\quad \mathrm{n}=10\end{array}$ & $\begin{array}{l}\text { ANOVA } \\
\text { test }\end{array}$ \\
\hline $\begin{array}{l}\text { Xanthine oxidase } \\
\text { (nM/min./mg } \\
\text { protein) }\end{array}$ & $2.55 \pm 1.2$ & $5.07 \pm 0.57^{* * * a}$ & $3.06 \pm 1.01^{* * * b}$ & $\begin{array}{l}F=19.23 \\
p<0.0001\end{array}$ \\
\hline $\begin{array}{l}\text { NADPH oxidase } \\
\text { (nM/min./mg } \\
\text { protein) }\end{array}$ & $0.85 \pm 0.33$ & $3.53 \pm 0.46^{* * * a}$ & $2.76 \pm 0.66^{* * * a,,^{* *} \mathbf{b}}$ & $\begin{array}{c}\mathrm{F}=67.32 \\
\mathrm{p}<0.0001\end{array}$ \\
\hline $\begin{array}{l}\text { ROS } \\
(\mu \mathrm{M} / \text { mg protein })\end{array}$ & $2.87 \pm 1.45$ & $7.47 \pm 1.79^{* * " a}$ & $4.51 \pm 0.82^{* \mathbf{a}, " * * \mathbf{b}}$ & $\begin{array}{l}F=27.31 \\
p<0.0001\end{array}$ \\
\hline
\end{tabular}

Data is expressed as mean \pm S.D. $\quad{ }^{\mathbf{a}}$ significance versus control (group I).

${ }^{\mathbf{b}}$ significance versus non-treated diabetic (group II). ${ }^{*} \mathrm{p}<0.05$, ${ }^{*} * \mathrm{p}<0.01$, ${ }^{*} *{ }^{*} \mathrm{p}<$ 0.0001 . 
TABLE (II): Testicular hemeoxygenase-1, Coenzyme Q10 and testosterone levels (ng/mg protein) in the studied groups.

\begin{tabular}{|c|c|c|c|c|}
\hline & $\begin{array}{c}\text { Group I } \\
\text { (control) } \\
n=10\end{array}$ & $\begin{array}{c}\text { Group II } \\
\text { (non-treated } \\
\text { diabetic) } \\
n=10\end{array}$ & $\begin{array}{c}\text { Group III } \\
\text { (atorvastatin- } \\
\text { treated diabetic) } \\
\mathrm{n}=10\end{array}$ & $\begin{array}{c}\text { ANOVA } \\
\text { test }\end{array}$ \\
\hline $\begin{array}{l}\text { Heme } \\
\text { oxygenase-1 } \\
\text { (ng/mg protein) }\end{array}$ & $157.2 \pm 34.91$ & $241 \pm 32.28^{* * * a}$ & $223.6 \pm 16.63^{* * * a}$ & $\begin{array}{c}\mathrm{F}=23.12 \\
\mathrm{p}<0.0001\end{array}$ \\
\hline $\begin{array}{l}\text { Coenzyme Q10 } \\
\text { (ng/mg protein) }\end{array}$ & $8.75 \pm 2.79$ & $3.69 \pm 1.51^{* * * \mathrm{a}}$ & $6.94 \pm 2.05^{* * \mathbf{b}}$ & $\begin{array}{l}F=12.31 \\
p<0.0001\end{array}$ \\
\hline $\begin{array}{l}\text { Testosterone } \\
\text { (ng/mg protein) }\end{array}$ & $1.24 \pm 0.23$ & $1.25 \pm 0.16$ & $1.52 \pm 0.30^{~ " a ~, ~ " ~ b ~}$ & $\begin{array}{l}F=4.58 \\
p=0.019\end{array}$ \\
\hline
\end{tabular}

Data is expressed as mean \pm S.D. $\quad{ }^{a}$ significance versus control (group I).

b significance versus non-treated diabetic (group II). ${ }^{*} \mathrm{p}<0.05$, ${ }^{* *} \mathrm{p}<0.01$, ${ }^{* * *} \mathrm{p}<$ 0.0001 .

TABLE (III): Serum levels of glucose and cholesterol $(\mathrm{mg} / \mathrm{dl})$ in the studied groups.

\begin{tabular}{|l|c|c|c|c|}
\hline & $\begin{array}{c}\text { Group I } \\
(\text { control) } \\
\mathrm{n}=10\end{array}$ & $\begin{array}{c}\text { Group II } \\
\text { (non-treated } \\
\text { diabetic) } \\
\mathrm{n}=10\end{array}$ & $\begin{array}{c}\text { Group III } \\
\text { torvastatin-treated } \\
\text { diabetic) } \\
\mathrm{n}=10\end{array}$ & $\begin{array}{c}\text { ANOVA } \\
\text { test }\end{array}$ \\
\hline $\begin{array}{l}\text { Serum glucose } \\
(\mathrm{mg} / \mathrm{dl})\end{array}$ & $110.1 \pm 11.32$ & $323.0 \pm 42.96^{* * * a}$ & $330 \pm 41.37^{* * * a}$ & $\begin{array}{c}\mathrm{F}=127.2 \\
\mathrm{P}<0.0001\end{array}$ \\
\hline $\begin{array}{l}\text { Serum } \\
\text { holesterol } \\
(\mathrm{mg} / \mathrm{dl})\end{array}$ & $58.2 \pm 9.3$ & $71.4 \pm 10.62^{* * a}$ & $62.5 \pm 8.25^{* \mathbf{b}}$ & $\begin{array}{l}\mathrm{F}=5.09 \\
\mathrm{P}=0.01\end{array}$ \\
\hline
\end{tabular}

Data is expressed as mean \pm S.D. $\quad{ }^{a}$ significance versus control (group I).

bignificance versus non-treated diabetic (group II). ${ }^{*} \mathrm{p}<0.05$, ${ }^{*} * \mathrm{p}<0.01$, **** $\mathrm{p}<$ 0.0001 . 
TABLE (IV): Pearson correlation between different studied parameters in all rats of the study.

\begin{tabular}{|c|c|c|c|c|c|c|}
\hline $\mathrm{n}=30$ & $\mathrm{XO}$ & $\begin{array}{c}\text { NADPH } \\
\text { oxidase }\end{array}$ & ROS & HO-1 & CoQ10 & Testosterone \\
\hline NADPH oxidase & $0.65^{* *}$ & - & & & & \\
\hline ROS & $0.82^{* *}$ & $0.63^{* *}$ & - & & & \\
\hline HO-1 & $0.77^{* *}$ & $0.81^{* *}$ & $0.84^{* *}$ & - & & \\
\hline CoQ10 & - & $-0.54^{* *}$ & - & - & - & \\
\hline Testosterone & $0.75^{* *}$ & & $0.90^{* *}$ & $0.75^{* *}$ & & - \\
\hline Glucose & $0.42^{*}$ & 0.35 & 0.11 & $0.54^{* *}$ & -0.03 & -188 \\
& & $0.55^{* *}$ & $0.69^{* *}$ & - & $0.52^{* *}$ & \\
\hline
\end{tabular}

Correlation coefficient (r) values. * significant at $\mathrm{p}<0.05$ (2-tailed), ${ }^{* *}$ significant at $\mathrm{p}<0.01$ (2-tailed).

ROS(reactive oxygen species), HO-1(hemeoxygenase-1), CoQ10(coenzyme Q10) .

\section{DISCUSSION}

Among various enzymes known to generate ROS, xanthine oxidase has been documented as an important biological source to produce $\mathrm{O}^{-\bullet}$ which plays central role in the development of diabetic complications $^{(4)}$.

In the present study the experimental diabetes induced by STZ in male albino rats, had caused a significant increase in the XO activity in the rat's testicular homogenates as compared with that assayed in the control non-diabetic rats. The activity of XO could reflect the activity of testicular tissue to generate ROS and thus the occurred oxidative stress could play a fundamental role in the changes that may occur in the testes as complications of diabetes.

This observation agreed with many previous reports in different diabetic rat tissues such as liver ${ }^{(7)}$ and plasma $^{(4)}$. Jin and his colleagues ${ }^{(7)}$ reported that xanthine oxidase was released from the liver of diabetic rats but not from the control non-diabetics, and this release was not the result of nonspecific protein leakage from the liver as other hepatic enzymes were not detected, neither in the diabetic nor in the control rat groups.

The finding of the present study agreed not only with results in experimental diabetes but also with that obtained from clinical studies, and this provides evidence for the possible contribution of the enzyme to oxidative stress and the pathophysiology of diabetes ${ }^{(27)}$.

Treatment of the diabetic rats with atorvastatin in this study resulted in a significant inhibition of the activities of the testicular xanthine oxidase of these animals as compared with the testicular enzyme activities in the diabetics who did not receive this treatment protocol. Here, atorvastatin through the inhibition of the activity of the oxidant-generating enzyme; $\mathrm{XO}$, could decrease the release of superoxide radicals and could provide 
a protective antioxidative effect to the testicular tissues against the enhanced diabetes induced-oxidative stress.

Bandoh et $\mathrm{al}^{(\mathbf{2 8})}$ reported that fluvastatin decreased reactive oxygen species such as hydroxyl radicals and superoxide anions, generated by the Fenton reaction and by the $\mathrm{XO}$ system, respectively.

In the current study, the activity of the enzyme NADPH oxidase of the testes was estimated as a possible pathway to generate ROS especially superoxide radicals. A significant increase in NADPH oxidase activity in the testes of diabetic rats was observed as compared with those in the non-diabetic controls. In the nondiabetic testes, NADPH oxidase has a very low constitutive activity that can be up-regulated in response to STZ induced hyperglycemia. This may contribute to the diabetic oxidative stress in the testis that may share in occurrence of testicular changes in diabetics.

These results were in agreement with previously reported studies ${ }^{(29,30)}$. Bubolz et $\mathrm{al}^{(\mathbf{3 0})}$ reported that there was enhancement of the $\mathrm{O}^{-\bullet}$ level observed in small coronary arteries from diabetic rats relative to non-diabetics. Apocynin, a specific inhibitor of NADPH oxidase, markedly decreased this high $\mathrm{O}^{-\bullet}$ level, indicating a significant role for the NADPH oxidase in generating oxygen radicals.

Avogaro and his colleagues ${ }^{(31)}$ studied monocytes from type 2 diabetic patients. They found increase in gene expression of $\mathrm{p} 22^{\text {phox }}$, a major component of NADPH oxidase, which testifies its increased activity. In addition, hyperglycemia in diabetes can upregulate NADPH oxidase through protein kinase $\mathrm{C}$ - dependent mechanism $^{(32) .}$

In the present study, when the diabetic rats were treated with atorvastatin, their testicular NADPH oxidase activity was significantly reduced. However, their levels did not return to the non-diabetic control values. So, atorvastatin could partially reverse the diabetic-induced oxidative stress. It seems likely that the antioxidant actions of statins are manifested via a variety of mechanisms and is at least partially due to inhibition of the activity of the enzyme NADPH oxidase, a major oxidant-generating enzyme in diabetes.

These findings were in agreement with many previous studies ${ }^{(33,34)}$. Wagner et $\mathrm{al}^{(34)}$ reported that although HMG-CoA reductase inhibitors did not have a direct antioxidative effect, they effectively inhibited endothelial $\mathrm{O}^{-\bullet}$ formation by preventing the isoprenylation of $\mathrm{p} 21 \mathrm{rac}$, which is critical for the assembly of NADPH oxidase after activation of protein kinase $\mathrm{C}$.

The streptozotocin-induced diabetics were associated with significant augmentation of the intensities of the DCF fluorescence as compared with that obtained from the control non-diabetics. As mentioned previously in this study, significant increase in the activity of the 2 major enzymes known in the pathways of the production of ROS; XO and NADPH oxidase, were detected in the testicular homogenates of the diabetic rats as compared with their activities in the testes from the non-diabetics. Diabetic status was associated with increased production of ROS, which 
in turn may be involved as a pathogenic mechanism for diabetic testicular complications.

These results were in agreement with many previously reported studies $^{(35,36)}$. Satoh et $\mathrm{al}^{(\mathbf{3 5})}$ reported that the DCF fluorescence in isolated glomeruli from diabetic rats was strong, indicating excessive $\mathrm{O}^{-\bullet}$ production. They suggested that NAD(P)H-dependent oxidase and nitric oxide synthetase but not $\mathrm{XO}$, are the predominant sources of superoxide radicals in the glomeruli of diabetic rats.

Administration of atorvastatin to the diabetic rats of the present study resulted in a significant reduction in the intensity of the fluorescence of the dye emitted from their testicular homogenates. Treating the diabetic rats with atrovastatin succeeded to decrease the release of ROS in their testes significantly. This effect was probably mediated through the detected inhibition of the activity of the enzymes; $\mathrm{XO}$ and NADPH oxidase. Atrovastatin provided antioxidant protective function to the testes in diabetic rats. However, their levels did not return to the nondiabetic control values; atorvastatin could partially reverse the diabeticinduced oxidative stress.

The present study confirmed a previous in vitro and in vivo study in rats ${ }^{(37)}$. They found that exposure of cultured aortic endothelial cells and smooth muscle cells to a high glucose level significantly increased oxidative stress, as evaluated by the staining with 2', 7'-DCFH-DA measurement. This increase was completely blocked by the treatment with pitavastatin which could attenuate the increased oxidative stress in STZ-diabetic rats through inhibition of vascular NADPH oxidase.

The significant positive correlation observed between the activities of $\mathrm{XO} \& \mathrm{NADPH}$ oxidase and DCF levels indicated that XO and NADPH oxidase may be major ROSproducing enzymes in the testes and the improvement in the oxidative stress induced by atorvastatin may be associated with their decreased activities. These data may suggest a possible antioxidant role of atorvastatin in testes.

In the present study, administration of atorvastatin to diabetic rats could significantly reduce the activities of $\mathrm{XO}$ and $\mathrm{NADPH}$ oxidase together with concomitant reduction in the testicular ROS contents. However, the best improvement in oxidative stress was more apparent at the level of XO activity; atrovastatin could reverse the diabetic-induced oxidative stress changes for XO activity with only partial attenuation of NADPH oxidase and ROS levels in testis of the studied rats.

Hemeoxygenase-1(HO-1) as inducible enzyme can monitor the changes that may occur in the testes of either STZ-induced diabetic rats or atorvastatin-treated diabetics. In the present study, HO-1 levels were significantly increased in the testes of the diabetic rats as compared to control non-diabetics. In response to the increase in the production of oxidants that was detected in the testicular homogenates of the present studied diabetic rats, the endogenous testicular antioxidant enzyme HO-1 was induced possibly to protect 
testicular tissue from oxidative damage and keep in vivo homeostasis. Positive correlations between HO-1 levels and each of the activity of ROS-generating enzymes and ROS levels could explain the role of HO-1 as adaptive molecule and strongly suggests the existence of a casual relationship between them. Morita ${ }^{(38)}$ supported the function of $\mathrm{HO}-1$ as adaptive molecule with antioxidant properties.

These findings were in agreement with previous reports of experimentally induced diabetes in different tissues ${ }^{(36,39)}$. Koya et $\mathrm{al}^{(\mathbf{3 6})}$ reported that both mRNA and protein expression of HO-1 were significantly increased in glomeruli of diabetic rats which may have protective roles against the development of diabetic nephropathy.

The cytoprotective effect of HO-1 may be due to release of its products biliverdin/ bilirubin and $\mathrm{CO}$, which act as antioxidants, anti-inflammatory and modulators of apoptosis ${ }^{(39,40,41,42)}$. The antioxidant activity of HO-1 in experimental diabetes can be evidenced by increased SOD and catalase enzymes ${ }^{(\mathbf{3 9})}$. Upregulation of HO-1 could also decrease cellular heme ${ }^{(40)}$ and increase reduced

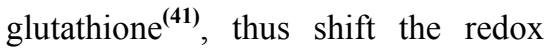
state to a reduced one. In testis, Leydig cells appear to use HO-1derived $\mathrm{CO}$ to trigger apoptosis of pre-meiotic germ cells and thereby modulate spermatogenesis under condition of stress $^{(\mathbf{4 2})}$.

Rodella et $\mathrm{al}^{(43)}$ found that hyperglycemia decreased HO activity, while exogenously administered $\mathrm{CO}$ and bilirubin (products of $\mathrm{HO}$ ) can prevent endothelial cell damage in diabetic rats via a decrease in oxidative stress.

Farhangkhoee et $\mathrm{al}^{(44)}$ demonstrated increased oxidative stress measured by increased 8hydroxydeoxy guanosine in association with increased HO1expression and activity in heart of STZ-induced diabetic rats. However, in non-diabetic rats, they found similar changes like those in diabetics after hemin (HO agonist) administration, thus suggesting a prooxidant activity of $\mathrm{HO}$ in heart.

The present data provided an evidence of increased HO-1 levels of STZ-induced diabetic testes; however the exact mechanism of its action needs further investigations.

The administration of atorvastatin to the diabetic rats of the present study did not cause any significant change in testicular HO-1 level, which denied an effect of atorvastatin on HO-1 in testis of diabetic rats. Despite extensive studies on the molecular mechanisms of statins, it remained unclear whether HO-1 was preferentially related to the cytoprotective effects of statins.

Lee et $\mathrm{al}^{(\mathbf{4 5 )}}$ found that simvastatin could not induce HO-1 either in aortic endothelial cells and macrophages in vitro culture or in vivo after $5 \mathrm{mg} / \mathrm{kg}$ i.p. injection in mesenchymal cells of lungs and kidneys. However, simvastatin preferentially induced HO-1 in hepatocytes and arterial vascular smooth muscle cells. In addition, statins could increase HO-1 expression, but not activity, in liver and brain of mice ${ }^{(46)}$. So, the HO-1 induction by statin seems to be tissuespecific without any role in testes of diabetic rats. 
Measuring testicular CoQ10 contents revealed significant lower contents in diabetic rats as compared to control non-diabetics. This result could be explained by partial depletion of the testicular CoQ10 contents as a result of oxidative stress induced by diabetes. The high level of ROS might exhaust the antioxidant capacity of CoQ10 in testes of diabetic rats. This suggestion could be confirmed, in this study, by the inverse correlation observed between COQ10 and each of ROS-generating enzymes; $\mathrm{XO}$ and NADPH oxidase, and ROS levels. These results supported the role of CoQ10 as antioxidant and membrane stabilizer $^{(\mathbf{1 2}, 47)}$. In diabetes, hyperglycemia increases the supply of electron donors, such as $\mathrm{NAD}(\mathrm{P}) \mathrm{H}$, which generates a high mitochondrial membrane potential, inhibiting electron transport at complex III. Electron transport and oxidative phosphorylation are uncoupled, resulting in inefficient ATP generation and transfer of electrons to molecular oxygen to form $\mathrm{O}^{-\bullet}$ and other free radicals. A quantitative or functional deficiency in CoQ10 in the presence of increased electron donors, exacerbates uncoupling of these two processes $^{(47,48)}$.

Several studies have been carried out to evaluate the alterations in mitochondrial functions of diabetic rats. However, results were sometimes controversial, since experimental conditions diverge, including age, the studied tissues and strain of used animal models.

Decreased CoQ10 level in diabetic rats of the present work confirmed the previous studies either in liver or heart of experimental diabetic rats ${ }^{(49)}$. Kucharska et al ${ }^{(49)}$ supposed that decreased tissue CoQ10 levels can be one of the causes leading to mitochondrial dysfunction in diabetes mellitus.

However, Palmeira et $\mathrm{al}^{(\mathbf{1 1 )}}$ reported that in the Goto-Kakizaki diabetic rat model, testicular mitochondria were less susceptible to oxidative stress due to increase in the antioxidants; GSH and CoQ9. This represented an adaptive response in this animal model. Salardi et al ${ }^{(50)}$ found that there was no change in the blood reactive oxygen metabolites, vitamin $\mathrm{E}$, and coenzyme Q10 levels of diabetic patients from age-matched control subjects. Coenzyme Q10 values were higher in patients with poor control than in those with good control of diabetes.

As coenzyme $Q$ shares a common biosynthetic pathway with cholesterol, so the inhibitors of HMG-CoA reductase as atorvastatin could also inhibit the CoQ biosynthesis. However, it is not usually the case. In a previous study Sprague-Dawley rats responded to simvastatin treatment for 2 weeks by a marked increase in lens cholesterol synthesis ${ }^{(51)}$. Thus, statins can have prounced effects on cells independent of inhibiting cholesterol biosynthesis; as an antioxidant ${ }^{(\mathbf{1 3})}$ and an anti-inflammatory ${ }^{\mathbf{5 2})}$ agents.

When diabetic rats, of the present study, received atorvastatin, CoQ10 contents of their testes were significantly higher compared to nontreated diabetics. This increase could reflect the drug-induced improvement in oxidative stress rather than the cholesterol synthesis-inhibition pathway. Although studies have 
repeatedly demonstrated either a reduction $^{(53)}$ or no effect ${ }^{(54)}$ of statin therapy on circulating CoQ10 concentrations, it is unclear as to whether tissue levels of CoQ10 were significantly affected. As an example, muscle CoQ10 concentration did not differ significantly between the statinrelated myopathy patients and control subjects $^{(\mathbf{5 5})}$. However, studies regarding the effect of statin on CoQ10 levels in diabetic testes are not available to compare with.

The testicular testosterone level was measured to evaluate the endocrine function of the Leydig cells. In the current study, non-significant change in the testicular testosterone levels was detected in the STZinduced diabetic rats as compared with that in the control non-diabetics. Thus, diabetes did not alter the steroidogenic function of testes.

Although, the increase in the oxidant production was detected in the testes of diabetic rats, but this was accompanied by enhancement of the activity of the endogenous antioxidant enzyme; HO-1. This provided some sort of endogenous protection to these testes against oxidative damage. The positive significant correlation between testosterone and HO-1 supported this suggestion.

The present finding was confirmed by Komaki et $\mathrm{al}^{(56)}$. They reported that although, there was no significant difference in serum levels of free testosterone between the male OLETF diabetic rats, a model of human type-2 diabetes, and the control LETO rats, the histological studies of their testes revealed atrophy of seminiferous tubules. Therefore, it would seem that the hypogonadism of diabetic rats may develop primarily in the form of testicular atrophy associated with decline in sperm count without change of interstitial tissue function and the circulating sex hormone. In contrast, some researchers demonstrated a decrease in plasma and testicular testosterone levels together with decreased androgen receptor expression in diabetic rats ${ }^{(57)}$

When the diabetic rats received atrovastatin for 8 weeks in this study, the testicular testosterone level was significantly elevated as compared with the diabetic animals who did not receive the treatment. This observation was actually in contrast of the fact that statins cause reduction in plasma cholesterol. As cholesterol is a precursor of steroid hormones, so inhibition of cholesterol biosynthesis can, in theory, adversely affect testicular secretion of testosterone either by decreasing the supply of the cholesterol to testes or by inhibiting in situ cholesterol synthesis ${ }^{(58)}$. Moreover, the poor bioavailability of statin in peripheral tissues, as testes, may not reflect the effects the agents are having in liver.

In this study, atorvastatin was found to have many effects against the occurrence of oxidative stress in the testes of diabetics; through inhibition of oxidants production together with enhancement of endogenous antioxidants. Atorvastatin actually could protect the testes of the diabetic rats against the enhanced oxidative damage; thus could cause an enhancement of testicular synthesis of the sex hormones.

Many previous studies demonstrated that the treatment of 
statins had no impact on steroidogenesis either in non-diabetic subjects $^{(\mathbf{1 4 , 5 8 )}}$ and rats ${ }^{(\mathbf{5 9 )}}$ or in diabetic patients $^{(60)}$ in spite of their significant effects on lowering total and LDLcholesterol levels. These results were cosistent with that of the present study.

Andreis et $\mathrm{al}^{(\mathbf{6 1 )}}$ reported that with prolonged lovastatin administration, Leydig cells progressively recovered their secretory activity due to a striking proliferation of smooth endoplasmic reticulum and peroxisomes, aimed at maintaining an adequate production of cholesterol (i.e. testosterone precursors) in spite of the chronic competitive inhibition of its synthesis through inhibition of HMG-CoA reductase enzyme.

Glycemic levels in all rats of this study showed direct correlation with ROS-producing enzymes and ROS levels and inverse correlation with antioxidant CoQ10 levels. These data point to the link between hyperglycemia and oxidative stress in testes. However the exact mechanisms of this stress in diabetes mellitus are not fully understood, hyperglycemia, polyol activation and glycation end products may share in ROS synthesis $^{(3)}$. Atorvastatin administration could not modulate STZ-induced hyperglycemia in the diabetic rats of this study which are confirmed by some investigators ${ }^{(\mathbf{1 3}) \text {. }}$

The present data, collectively, could provide an evidence of oxidative stress in testes of STZinduced diabetic rats. Atorvastatin administration could attenuate this stress not only by decreasing ROSproducing enzyme activities and ROS levels but also by improving the antioxidant CoQ10 levels. Thus, atorvastatin can act through cholesterol-dependant and independent antioxidant mechanisms but without any apparent effect on hyperglycemia or HO-1 modulation.

\section{REFERENCES}

1. Seftel A (2006). Male hypogonadism. Part II: etiology, pathophysiology, and diagnosis. Int J Impot Res; 18 (3): 223-8.

2. Naziroglu M (2003). Enhanced testicular capacity in streptozotocin-induced diabetic rats: protective role of vitamins $\mathrm{C}$ and $\mathrm{E}$ and selenium. Biol Trace Elem Res; 94 (1): 61-72.

3. Niedowicz DM, Daleke DL (2005). The role of oxidative stress in diabetic complication. Cell Biochem Biophys; 43(2): 289-330.

4. Desco MC, Asensi M, Marquez R, Martinez-Valls J, Vento $M$, Pallardo FV, Sastre J, Vina J (2002). Xanthine oxidase is involved in free radical production in type 1 diabetes: protection by allopurinol. Diabetes; 51: 1118-24.

5. Li JM, Shah AM (2003). ROS generation by nonphagocytic NADPH oxidase: potential relevance in diabetic nephropathy. J Am Soc Nephrol; 14: S 221-6.

6. Meneshiam A, Bulkley GB (2002). The physiology of xanthine oxidase: from urate catabolism to reperfusion injury to inflammatory signal transduction. Microcirculation; 9: 161-75. 
7. Jin DQ, Li G, Kim J S, Yong CS, Kim JA, Huh K (2004). Preventive effects of Laminaria japonica aqueous extract on the oxidative stress and xanthine oxidase activity in streptozotocininduced diabetic rat liver. Biol Pharm Bull; 27 (7) 1037-40.

8. Babior BM, Lambeth JD, Nauseef W (2002). The neutrophil NADPH oxidase. Arch Biochem Biophys; 397 (2): 3424.

9. Banfi B, Molnar G, Maturana $A$, Steger $\mathbf{K}$, Hegedus $\mathbf{B}$, Demaurex N, Krause K (2001). A $\mathrm{Ca}^{++}$-activated NADPH oxidase in testis, spleen, and lymph nodes. J Biol Chem; 276 (40): 37594-601.

10. Shiraishi K, Naito $K$ (2005). Increased expression of Leydig cell hemeoxygenase-1 preserves spermatogenesis in varicocele. Human Reprod; 20 (9): 2608-13.

11. Palmeira CM, Santos DL, Seiça R, Moreno AJ, Santos MS (2001). Enhanced mitochondrial testicular antioxidant capacity in Goto-Kakizaki diabetic rats: role of coenzyme Q. Am J Physiol Cell Physiol; 281: C 1023-8.

12. Cendrella RJ, Neely AR, Sexton $P$ (2005). Concentration and distribution of ubiquinone (coenzyme Q), the endogenous lipid antioxidant, in the rat lens: effect of treatment with simvastatin. Mol Vis; 11: 594602.

13. Mahfouz MM, Kummerow FA (2005). Atorvastatin reduces the plasma lipids and oxidative stress but did not reverse the inhibition of prostacyclin generation by aortas in streptozotocin diabetic rats. Prostaglandins Other Lipid Mediat; 76(1-4): 59-73.

14. Bohm M, Herrmann W, Wassmann S, Laufs U, Nickenig $G$ (2004). Does statin therapy influence steroid hormone synthesis? Z Kardiol; 93(1): 43-8.

15. Danesh FR, Kanwar YS (2004). Modulatory effects of HMG-CoA reductase inhibitors in diabetic microangiopathy. FASEB; 18: 805-15.

16. Ceriello A (2006). Oxidative stress and diabetes-associated complications. Endocr Pract;12 (Suppl 1): 60-2.

17. Lowry OH, Rosebrough NJ, Farr AL, Randall RJ (1951). Protein measurement with the folin phenol reagent. $\mathrm{J}$ Biol Chem; 193: 265-75.

18. Kaminski ZW, Jezewska MM (1979). Intermediate dehydrogenase-oxidase form of xanthine oxidoreductase in rat liver. Biochem J; 181 (1): 17782.

19. Van Gelder BF, Slater EC (1962). The extinction coefficient of cytochrome c. Biochim Biophys Acta; 58: 593-5.

20. Tamura $M$, Tamura $T$, Tyagi $S$, Lambeth J (1988). The superoxide-generating respiratory burst oxidase of human neutrophil plasma membrane. J Biol Chem; 263 (33): 17621-6.

21. Keston A, Brandt R (1965). The fluorometric analysis of ultramicro quantities of hydrogen peroxide. Anal Biochem; 11: 1- 5.

22. Bass D, Prace J, Dechatelet $\mathbf{L}$, Szejda P, Seeds M, Thomas M 
(1983). Flow cytometric studies of oxidative product formation by neutrophils: A graded response to memberane stimulation. J Immunol; 130: 1910-7.

23. Araujo J, Meng L, Tward A, Hancocks W, Zhai Y, Lee E, Ishikawa $\mathrm{K}$, Iyer S, Buelow R, Busuttil R, Shih D, Lusis A, Kupiec-weglinski J (2003). Systemic rather than local heme oxygenase-1 overexpression improves cardiac allograft outcomes in a new transgenic mouse. J Immunol; 171: 1572-80.

24. Ikenoya S, Takada M, Yuzuraki T, Abe K, Katayama A (1981). Studies on reduced and oxidized ubiquinones I. Simultaneous determination of reduced and oxidized ubiquinones in tissues and mitochondria by high performance liquid chromatography. Chem Pharm Bull; 29 (1): 158-64.

25. Li K, Shi Y, Chen S, Li W, Shang $X$, HuangY (2006). Determination of coenzyme Q10 in human seminal plasma by high-performance liquid chromatography and its clinical application. Biomed Chromatogr; 20(10):1082-6.

26. Wasser $S \mathrm{~K}$, Monfort $\mathrm{S} \mathbf{L}$, Wildt D E (1991). Rapid extraction of faecal steroids for measuring reproductive cyclicity and early pregnancy in freeranging yellow baboons (Papio cynocephalus cynocephalus). J Reprod Fertil; 92: 415-23.

27. Kuppusamy UR, Indran $M$, Rokiah P (2005). Glycaemic control in relation to xanthine oxidase and antioxidant indices in
Malaysian Type 2 diabetes patients. Diabet Med; 22 (10): $1343-6$.

28. Bandoh T, Sato EF, Mitani H, Nakashima A, Hoshi K, Inoue M (2003). Antioxidative potential of fluvastatin via the inhibition of nicotinamide adenine dinucleotide phosphate (NADPH) oxidase activity. Biol Pharm Bull; 26 (6): 818-22.

29. Kitada M, Koya D, Sugimoto T, Isono M, Araki S, Kashiwagi A, Haneda M (2003). Translocation of glomerular p47phox and p67phox by protein kinase C- $\beta$ activation is required for oxidative stress in diabetic nephropathy. Diabetes; 52: 260314.

30. Bubolz AH, Li H, Wu Q, Liu Y (2005). Enhanced oxidative stress impairs cAMP-mediated dilation by reducing $\mathrm{K}_{\mathrm{v}}$ channel function in small coronary arteries of diabetic rats. Am J Physiol Heart Circ Physiol; 289: 1873-80.

31. Avogaro A, Elisa Pagnin E, Calò $L$ (2003). Monocyte NADPH oxidase subunit $\mathrm{p} 22^{\text {phox }}$ and inducible hemeoxygenase-1 gene expressions are increased in type II diabetic patients: relationship with oxidative stress. J Clin Endocrinol Met; 88: 17539.

32. Xia L, Wang H, Golgberg HJ, Mark S, Fantus IG, Whiteside CI (2006). Mesangial cell NADPH oxidase upregulation in high glucose is protein kinase $\mathrm{C}$ dependent and required for collagen IV expression. Am J Physiol Renal Physiol; 290 (2): F 345-56. 
33. Takayama T, Wada A, Tsutamoto T, Ohnishi M, Fujii $M$, Isono $T$, Horie $M$ (2004). Contribution of vascular $\mathrm{NAD}(\mathrm{P}) \mathrm{H}$ oxidase to endothelial dysfunction in heart failure and the therapeutic effects of HMGCoA reductase inhibitor. Circ J; 68: $1067-75$.

34. Wagner AH, Köhler T, Rückschloss U, Just I, Hecker M (2000). Improvement of nitric oxide-dependent vasodilatation by HMG-CoA reductase inhibitors through attenuation of endothelial superoxide anion formation. Arterioscler Thromb Vasc Biol; 20: 61- 9.

35. Satoh M, Fujimoto S, HarunaY, Arakawa S, Horike H, Komai N, Sasaki T, Tsujioka K, Makino H, Kashihara N (2005). $\mathrm{NAD}(\mathrm{P}) \mathrm{H}$ oxidase and uncoupled nitric oxide synthase are major sources of glomerular superoxide in rats with experimental diabetic nephropathy. J Physiol Renal Physiol; 288: 1144-52.

36. Koya D, Hayashi K, Kitada $M$, Kashiwagi A, Kikkawa R, Haneda M (2003). Effects of antioxidants in diabetes-induced oxidative stress in the glomeruli of diabetic rats. $\mathrm{J}$ Am Soc Nephrol; 14: S 250-3.

37. Tsubouchi H, Inoguchi T, Sonta T, Sato N, Sekiguchi N, Kobayashi K, Sumimoto H, Utsumi H, Nawata H (2005). Statin attenuates high glucoseinduced and diabetes-induced oxidative stress in vitro and in vivo evaluated by electron spin resonance measurement. Free
Radic Biol Med; 15-39(4): 44452.

38. Morita $T$ (2005).

Hemeoxygenase and atherosclerosis. Arterioscler Thromb Vasc Biol ; 25 (9): 1786 -95 .

39. Turkseven S, Kruger A, Mingone CJ, Kaminski $\mathbf{P}$, Inaba M, Rodella LF, Ikehara S, Wolin MS, Abraham NG (2005). Antioxidant mechanism of heme oxygenase-1 involves an increase in superoxide dismutase and catalase in experimental diabetes. Am J Physiol Heart Circ Physiol; 289 (2): H 701-7.

40. Abraham NG, Rezzani R, Rodella L, Kruger A, Taller D, Li VG, Goodman AI, Kappas A (2004). Over expression of human hemeoxygenase-1 attenuates endothelial cell sloughing in experimental diabetes. Am J Physiol Heart Circ Physiol; 287: H 2477-7.

41. Quan S, Yang L, Shenouda S, Schwartzman ML, Nasjletti A, Goodman AI, Abraham NG (2004). Expression of human hemeoxygenase- 1 in the thick ascending limb attenuates angiotensin II-mediated increase in oxidative injury. Kidney Int; 65: $1628-39$.

42. Ozawa N, Goda N, Makino N, Yamaquchi T, Yoshimura Y, Suematsu M (2002). Leydig cellderived heme oxygenase-1 regulates apoptosis of pre-meiotic germ cells in response to stress. J Clin Invest;109(4): 457-67.

43. Rodella L, Lamon BD, Rezzani R, Sangras B, Goodman AI, Folch JR, Abraham NG (2006). 
Carbon monoxide and biliverdin prevent endothelial cell sloughing in rats with type I diabetes. Free Radic Biol Med; 40 (12): 2198 205.

44. Farhangkhoee H, Khan ZA, Mukherjee S, Cukiernik $M$, Barbin YP, Karmazyn M, Chakrabarti S (2003). Hemeoxygenase in diabetesinduced oxidative stress in the heart. J Mol Cell Cardiol; 35 (12): 1439-48.

45. Lee T-S, Chang C-C, Zhu Y, Shyy J Y-T (2004). Simvastatin induces heme-oxygenase-1. A novel mechanism of vessel protection. Circulation; 110: 1296-302.

46. Hsu M, Muchova L, Morioka I, Wong RJ, Schroder H, Stevenson DK (2006). Tissuespecific effects of statins on the expression of heme oxygenase-1 in vivo. Biochem Biophys Res Commun; 343 (3): 738-44.

47. Crane FL (2001). Biochemical functions of coenzyme Q10. J Am Coll Nutr; 20: 591-8.

48. Evans JL, Goldfine ID, Maddux BA, Grodsky GM (2003). Are oxidative stressactivated pathways mediators of insulin resistance and $\beta$-cell dysfunction? Diabetes; 52: 1-8.

49. Kucharska J, Braunova Z, Ulicana O, Zlatos L, Gvozdjakova A (2000). Deficit of coenzyme $\mathrm{Q}$ in heart and liver mitochondria of rats with streptozotocin-induced diabetes. Physiol Res; 49: 411-8.

50. Salardi S, Zucchini S, Elleri D, Grossi G, Bargossi A M, Gualandi S, Santoni R,
Cicognani A, Cacciari E (2004). High glucose levels induce an increase in membrane antioxidants, in terms of vitamin $\mathrm{E}$ and coenzyme Q10, in children and adolescents with type 1 diabetes. Diabetes Care; 27: 6301.

51. Cenedella RJ, Kuszak JR, AlGhoul KJ, Qin S, Sexton PS (2003). Discordant expression of the sterol pathway in lens underlies simvastatin-induced cataracts in Chbb-Thom rats. J Lipid Res; 44: 198-211.

52. Takemoto M, Liao JK (2001). Pleiotropic effects of 3-hydroxy3-methylglutaryl coenzyme A reductase inhibitors. Arterioscler Thromb Vasc Biol; 21: 1712-9.

53. Colguhoum DM, Jackson R, Walters M, Hicks BJ, Goldsmith J, Young $\mathbf{P}$, Strakosch C, Kostner KM (2005). Effects of simvastatin on blood lipids, vitamin E, Coenzyme Q10 levels and left ventricular function in humans. Eur J Clin Invest; 35( 4): 251-8.

54. Bleske BE, Willis RA, Anthony M, Casselberry N, Datwani $M$, Uhley VE, Secontine S G, Shea MJ (2001). The effect of pravastatin and atorvastatin on coenzyme Q10. Am Heart J; 142 (2): E2.

55. Lamperti $C$, Naini AB, Lucchini V, Perella A, Bresolin N, Moggio M, Sciacco M, Kaufmann P, DiMauro S (2005). Muscle coenzyme Q10 level in statin-related myopathy. Arch Neurol; 62 (11)1709-12.

56. Komaki K, Ohno Y, Aoki N (2005). Gonadal hormones and 
gonadal function in type-2 diabetes model OLETF ( Otsuka Long Evans Tokushima Fatty) rats. Endo J; 52: 345-51.

57. Liu SH, Wang ZS (2005). Study on the expression of androgen receptor in testis, epididymis and prostate of adult rats with diabetes. Zhonghua Nan Ke Xue; 11(12): 89-4.

58. Dobs AS, Miller S, Neri G, Weiss S, Tate AC, Shapiro DR, Musliner TA (2000). Effects of simvastatin and pravastatin on gonadal function in male hypercholesterolemic patients. Metabolism; 49: 115-21.

59. Dostal LA, Whitfield LR, Anderson JA (1996). Fertility and general reproduction studies in rats with the HMG-CoA reductase inhibitor, atrovastatin. Appl Toxicol; 32: 285-92.

60. Santini SA, Carrozza C, Lulli P, Zuppi C, Tonolo GC, Musumeci S (2003). Atorvastatin treatment does not affect gonadal and adrenal hormones in type- 2 diabetes patients with mild to moderate hypercholesterolemia. J Atheroscler thromb; 10 (3): 1604.

61. Andreis PG, Cavallini L, Mazzocchi G, Nussdorfer GG (1990). Effects of prolonged administration of lovastatin, an inhibitor of cholesterol synthesis, on the morphology and function of rat Leydig cells. Exp Clin Endocrinol; 96 (1): 15-24.

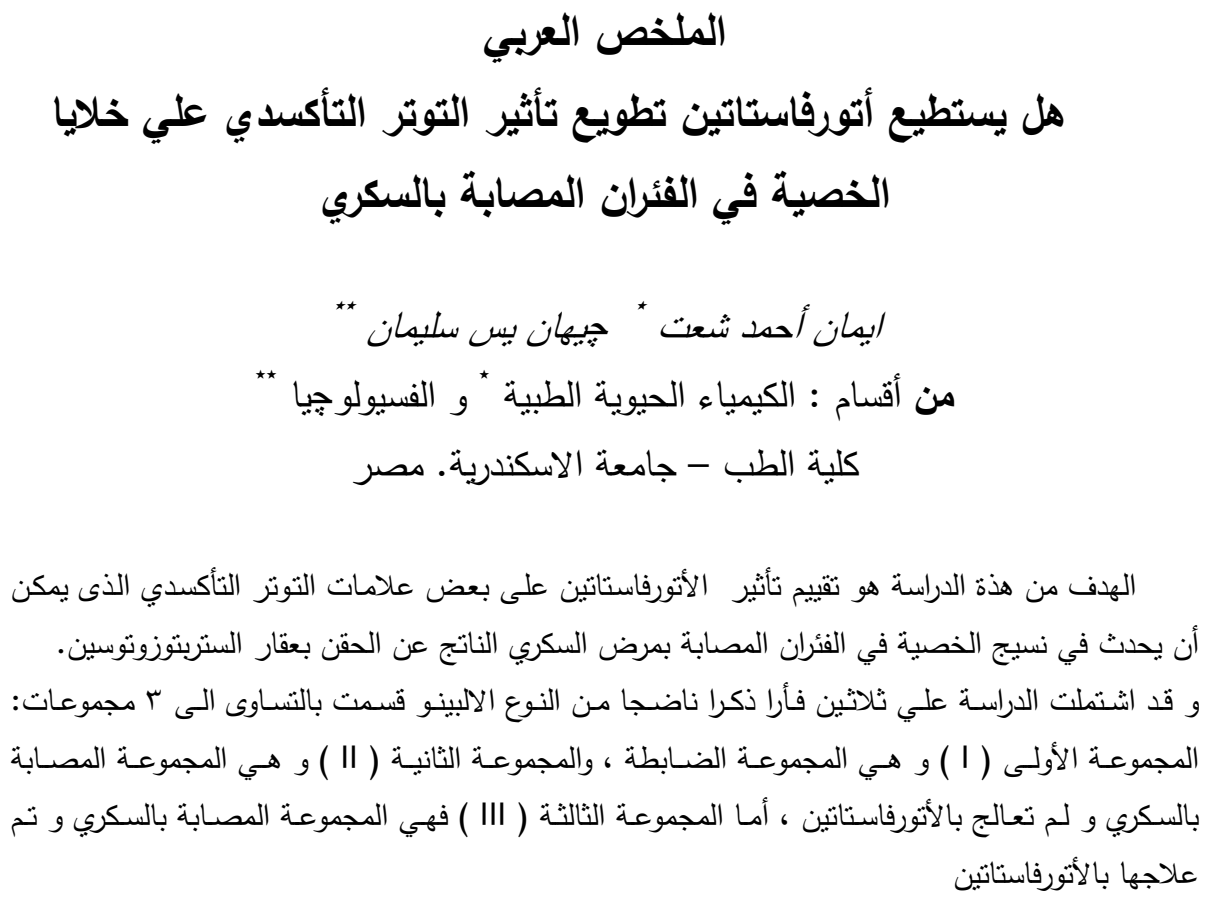


و قد استمرت الدراسة لمدة $\wedge$ اسابيع • وبعد استئصال الخصيتين تم اجراء القياسات التالية فيها : قيـاس نشـاط انزيمسى الزانسـين أوكسيبيداز و ن .أ.د.ب. أوكسيداز و مسـتوى الثـطائر المؤكسـدة و مسـتوى الهيمؤكسيجينيز - ا و كوانزيم كيو · ل و مستوي هرمون التستوستيرون.

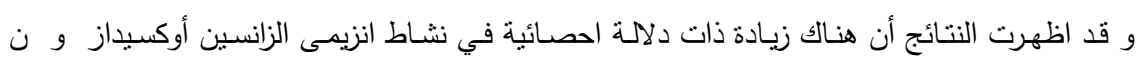
أ.د.ب. أوكسيداز و مستوى الشطائر المؤكسدة و مستوى الهيمؤكسيجينيز -1 في الفئران المصابة بالسكري و

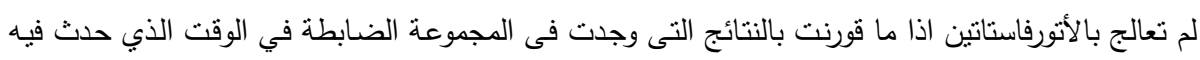
نقص ذو دلالة احصائية فى مستوى كوانزيم كيو · 1 .

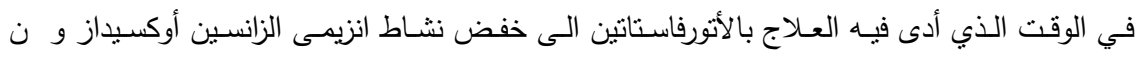

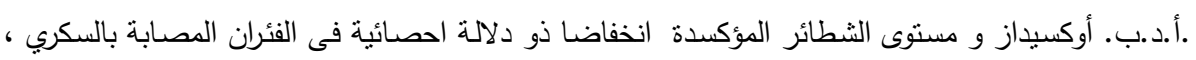

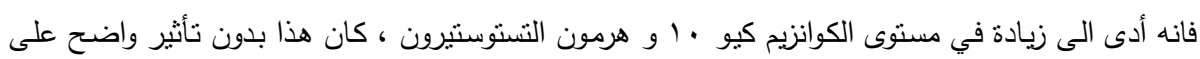

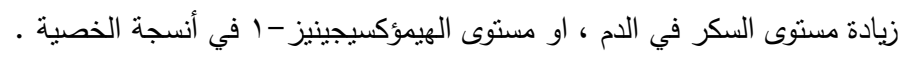
وجد أن هناك علاقة أحصائية طرديه بين نشاط الأوكسيداز و ن .أ.د.ب. أوكسيداز و مستوى الثطائر المؤكسدة و مستوى الهيمؤكسيجينيز - ا و مستوى الجلوكوز فى الوقت الذى كانت العلاقة الاحصائية عكسيه بين الكوانزيم كيو ـأ وكل هذة القياسات السابق ذكرها.

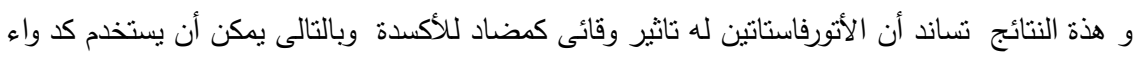
لخفض التوتز التأكسدي في الخصيتين و الناتج عن الاصـابة بمرض السكري الناتج عن حقن الفئران بعقار الستربتوزوتوسين ، و الذي يمكن أن يحدث من خلال انخفاض نشاط انزيمى الزانسين أوكسيداز و ن .أ.د.ب.

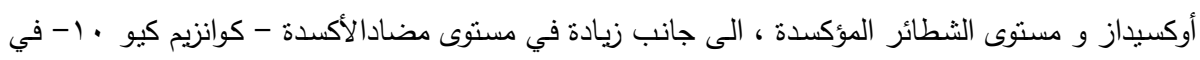

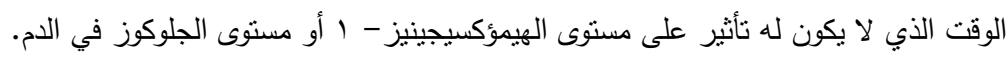

